\title{
A cross-language perspective on the MAIDAN-concept
}

\section{Olesia Yehorova \& Antonina Prokopenko}

\author{
Sumy State University, Ukraine
}

\begin{abstract}
As the constituents of thoughts, concepts play a key role in human's categorisation and interpretation of the surrounding world, in fixing our cognitive experience and forming individual judgements. The paper considers the representation of the nationally biased (ethno-specific) concept MAIDAN as one of those functioning not only in Ukrainian but also in pan-European and global socio-political discourses of the recent years. Specifically, leaning on lexicographic data the study focuses on reconstructing the notional layer (informative core) of the concept and on identifying the differences of its content as featured in kin Slavic (Ukrainian and Russian) and distant Germanic (English and German) languages and linguocultures. The paper suggests a consecutive methodology based on lexicographic methods of analysis. Such methodology helps to define the sets of notional conceptual features subjected to further comparative interpretation. The procedures described in this paper give way to subsequent stages of conceptual analysis and discourse representations. The paper also provides preliminaries to the state of inconsistency between the systemic and utterance meanings of the language expressions of MAIDAN-concept that pose a limitation for comprehending the concept when transmitted to a different linguoculture
\end{abstract}

Key words: linguoconceptology; MAIDAN-concept; notional layer; semantic summand; conceptual feature.

\section{Introduction}

Both the $20^{\text {th }}$ and the $21^{\text {st }}$ centuries have witnessed an avalanche of uprisings and protest movements spared on a global scale: February Revolution in Russia, Bloody Sunday in the UK, Soweto Uprising in South Africa, Velvet Revolution in Czechoslovakia, Tiananmen Square Protests in China, Arab spring in Arabic world, Occupy Seattle in the USA, etc. Any uprising of the kind aims at breaking the established conventions and renewing social and political practices. However, a protest movement is ethnocentric and thus unconventional. In pursuit of the same goal - to bring about changes of the current state of affairs - protest movements differ in subjects and objects of 
confrontation, objectives, tools, and measures applied as well as their ultimate social impact and the historic imprints they leave afterward.

Ukrainian Maidan of 2013-2014, also known as Euromaidan Revolution or Revolution of Dignity, was a series of continuous protests across Ukraine with its epicentre in Kiev. Over the last three decades, this uprising became one in the series of Maidan-movements in the history of Ukraine; however, this particular event of 2013-2014 has drawn the utmost world's attention to the democratic processes in the post-Soviet Ukraine. Inland and abroad, many people saw this revolution as a way to establishing a new conceptualisation of global values and sentiments in favour of economic, political and social integration of Ukraine into the European and global community.

Due to the vast media coverage worldwide, in winter of 2013-2014, there could hardly be found a person who had not heard about the Maidan events, at least by hearsay. Nevertheless, the most typical imprint of the events, found on Wikipedia, is reduced to "... a wave of demonstrations and civil unrest in Ukraine, which began on the night of 21 November 2013 with public protests in Maidan Nezalezhnosti ('Independence Square') in Kiev, demanding closer European integration"(https://en.wikipedia.org/ wiki/Euromaidan).

In the context of Ukrainian socio-political discourse, the word maidan has become a synonym for protest, revolt, and resistance. But what is maidan per se? Can the content of the MAIDAN-concept be reduced to the images and judgements found in the news coverage? Does one need to learn more about the lexical actualisation of the concept to get a deeper insight into the phenomenon of Maidan? These are some of the questions we try to answer in this study from the perspective of linguocognitology which aims at explaining concepts of reality resting on their lingual (verbalised) reconstruction in language and discourse.

Concepts appear as products of both individual and collective cognition. Concepts that constitute collective cognition may be found in different linguocultures and treated as universal or appear in a sole linguoculture and considered ethno-specific. Following Ronald Langacker (1987: 488), who recognises domain as a coherent area of conceptualisation, we identify the domains like 'protest', 'revolution' and 'uprising' and analyse one of the units pertaining to all these domains that we call MAIDAN-concept ${ }^{1}$.

MAIDAN belongs to the class of non-fundamental ethno-specific lexical concepts. Unlike grammatical concepts which constitute the fundamental conceptual structuring system of language (Talmy, 2000) and reflect correlations between facts of objective world (e.g. concepts TIME, QUANTITY, POSSES-

\footnotetext{
${ }^{1}$ From here on, in this paper 'MAIDAN' will refer to the concept as a unit of knowledge, whereas 'Maidan' and 'maidan' will be applied for designating the facts of reality.
} 
SION, etc.), lexical concepts make up an open class of cognitive structures that store information about separate facts of reality (concepts FIRE, TERRORISM, LOVE, HOME, FOOD, etc.).

MAIDAN is a unique concept of the Ukrainian spiritual culture that marks today's Ukrainian society, identity, symbolism and socio-political practices. All this speaks for its ethno-specific character. Monika Schwarz (1996: 88) suggested denoting such type of concepts 'Token-Konzepte' ('conceptssymbols' or 'idioconcepts') in reference to the nationally significant images in the mental lexicon of people.

Vyvyan Evans (2009) defines the bipartite organisation of lexical concepts that comprises both linguistic content (semantic structure) and conceptual content (conceptual structure). He rightfully claims that language as a representational system consisting of symbolic units is simply not equipped to directly encode the rich, multimodal character of sense-perceptory and subjective experience that form the richness of conceptual content (Evans, 2009: 105). However, following Humboldtian tradition to regard language as a tool for structuring the human thought, we treat language as a point of entry for linguists to analyse the world's construal in human cognition. Thus, we believe that investigation into the aspects of the linguistic content of the MAIDAN-concept will contribute to accessing the conceptual ('above'language) side of the lexical concept.

Despite the lack of unanimity among linguists as to the structure of concepts and naming its constituent parts, many of them tend to distinguish three main layers within the conceptual structure: notional ('informative' or 'factual'), image-sensual and evaluative ('interpretative') (Vorkachev, 2005; Karasik, 2005; Nikitin, 2007; Popova \& Sternin, 2007; Prykhodko, 2013; etc.).

The notional layer of concept reflects its denotative connection to the conceptual referent - 'a minimal self-reliant sector of mental space, a unique cognitive bundle' (Prykhodko, 2013: 21). It accumulates the core actual features of the concept, the most considerable ones for the fact of reality related to the concept that help to differentiate the concept from other concepts. Image-sensual layer stores all emotional, associative and experiential knowledge of a person or a community which is triggered by a particular denotatum. Evaluative layer defines the status of concept within the conceptual worldview of the nation; it is made up of interpretations and assessments as to the significance of the concept for an individual, for a social group or nation at large.

As so often with most concepts, time and space modify their content (cf. the content of WAR-concept in times of Roman Empire and The Third Reich or its representation in Mursi and American cultures or the 'Islamic State' ideology). Boldyrev (2001: 30) metaphorically calls concept a snowball that is rolling down the hill and acquiring new layers. Thus, the flexibility of a con- 
ceptual structure is seen as a prerequisite for its functioning in the conceptual domain, and the concept's inner form along with its content, stored in the core layer, set the motion for all follow-ups.

\section{Methods and materials}

At this stage, we start from the assumption that all the concepts which are meaningful for the nation get reflected in the language system, and in the case of lexical concepts - in the lexical subsystem. Supporting Oriikiriza (2014), in this study of MAIDAN-concept, we recognise the lexical meaning of its key nomination (words Maidan-/maidan) as a set of sense, reference, usage and utterance meanings of a word:

A sense in this context refers to the basic meaning of a word, while reference refers to the extended meanings. The usage meaning is associated with the social usage of the word. [...] They may also have meanings resulting from the speech act with which the word is used. The meanings, in this case, are referred to as utterance meanings (Oriikiriza, 2014: 228-229).

We also agree with Oriikiriza (2014) on attributing sense and reference meanings to conceptual meanings, and the usage and speech act meanings to interpersonal ones. However, in this study, we focus on analysing the 'sense sector' - the innermost notional layer of MAIDAN-concept that stores the initial data and basic prototypes of the referent and provides access to the cultural sense of the concept necessary for its adequate treatment. We believe that recourse to dictionaries as information sources is an appropriate approach here due to the fact that dictionary glosses are authentic witnesses of the semantic content of lexical units both in synchrony and diachrony.

The application of lexicographic methods is possible after clarifying the headword that would lead to the dictionary entry containing its sense interpretations. In terms of conceptology, such headword should represent a language unit (or a set of units) rendering the conceptual content to the fullest extent possible. A product of such immediate concept labelling in language is called key nomination (name) or prime verbaliser. Among general requirements to such naming are the frequency of use, sufficient generality of semantics, desirable stylistic neutrality, referentiality to the fact of common knowledge and significance for the language users (Popova \& Sternin, 2007: 125).

Ukrainian revolution of 2013-2014 has entered the international lexicon under the names of Maidan and maidan (sometimes also its derivative Euromaidan). As long as no strict distinction rules as to its capitalisation have been established, we regard these lexemes as the key nominations of the corresponding concept MAIDAN. However, we treat the lexeme Maidan as a 
tertiary derivative in the chain of (Euro)Maidan > Maidan Nezalezhnosti (Square of Independence in Kiev) > maidan. Thus, we consider maidan a proto-name of the nomination Maidan and the initial point for interpreting the notional content of MAIDAN-concept.

The notional content of any concept is exposed through a set of informative cognitive tokens. This set is regarded as a definitional minimum of features that determines the heart of the concept. As long as the informative content of many concepts is close to the definition of the key nomination of the concept (Popova \& Sternin, 2007: 77) and is conventionally fixed by lexicographic sources (Prykhodko, 2013: 22), in this study we apply the methods of definitional analysis the appropriateness of which has been neatly observed by Karaulov (1981: 278): “... taken ... per se, dictionary definitions from the right side of the entry [the gloss] represent nominal or nominalised word-combinations approximately semantically equal to the nominal element (word) of the left side of the entry [lemma headword]".

Anticipating the language expression, the human's initial cognitive experience of reality gets fixed in the 'inner form' of a word, also called etymon (from Greek हैivpov 'the true sense of a word according to its origin', from Étopos 'true' (LSJ, 1940: 593)). Etymon is an embryonic core of sense with reference to which the current usages of the word function as metaphors (Freidin, 1987: 162). Thus, the current study applies to etymological dictionaries to establish the etymon of the key nomination of MAIDAN-concept.

The further analysis aims at explicating the actual sense meaning of the unit maidan as it appears in the lexical systems of the distant languages. For this, we address the dictionaries of two genealogically heterogeneous language groups: Slavic, comprising Ukrainian and Russian, and Germanic, presented by English and German. This choice arises from following factors: the former two expose a long history of operation of MAIDAN-concept in Slavic tradition and share up to $62 \%$ of the total vocabulary (Tyshchenko, 2010); the latter two belong to major mediators for the cross-cultural communication today.

Lexicographic sources of all languages under study contain a maidan entry; thus, the application of componential analysis enables stating the semic composition of the plane of content and deriving conceptual features of the word from the set of semes that form sememe. The ultimate goal of these procedures is to define the semantic zones of convergence and divergence within the maidan nominations in Slavic and Germanic languages. Specifically, it will allow for the estimation of the factual potential of English and German to faithfully render the notional layer of the MAIDAN-concept to the representatives of other linguocultures.

Lexicographic sources of Slavic languages. Dictionary of the Ukrainian Language (SUM) in 11 volumes historically became the first explanatory dic- 
tionary of Ukrainian. Compiled and edited by a vast number of scholars, it has laid the foundations of almost all modern Ukrainian dictionaries. Signs of the Ukrainian Ethnic Culture (ZUEK) - labelled by its author as 'dictionaryreference' - poses a successful effort of today to compile a glossary of the Ukrainian language units of ethnocultural value. Its lexicographic glosses offer linguistic and encyclopaedic descriptions of ethnocultural concepts ('signs of ethnic culture'). These are specific language products that arise from the intertwined ethnic symbolism of words and their actual referents.

Explanatory Dictionary of the Living Great Russian Language (DTS) by Vladimir Dahl is a fundamental work of Russian philological and scientific thought. First published more than 150 years ago, it enjoys popularity and authority in the 21st century. The dictionary features commentaries on general, dialectic, professional and everyday use of lexical units and introduces to language-related popular beliefs and omens. The dictionary provides its users with extra ethnographic and ethnocultural information that helps to explicate the sense and reference meaning of lemmas.

Another source of reference is Explanatory Dictionary of the Russian Language (UTS), also called Ushakov's Dictionary after the name of its editor Dmitry Ushakov. The source is topical for this study due to its normative character (compiled on V. Lenin's initiative as an 'exemplary dictionary of classic Russian'), the elaborated system of labelling and a profound theoretic effect on subsequent lexicographic activity as applied to many national languages of the former Soviet Union.

Lexicographic sources of Germanic languages. Aiming at the objectivity of the study, we use two of the most renowned explanatory dictionaries of both British and American English.

Oxford English Dictionary (OED) has proved high prestige with scholars and practitioners and contains the uttermost knowledge database that stores up a long-stay conceptual memory of the language users.

Collaborative International Dictionary of English (CIDE) was derived from the Webster's Revised Unabridged Dictionary (1913) and supplemented with some of the definitions from WordNet. The dictionary is seen as a potential starting point for the development of a modern comprehensive encyclopaedic dictionary freely accessed on the Web.

Unlike English, none of the contemporary German language dictionaries (Duden, PONS, Langenscheidt, DWDS, etc.) contains the entry maidan. Among those few relevant lexicographic sources indexing the respective language unit, we chose Brockhaus' Kleines Konversations-Lexikon (BKKL) and Meyers Großes Konversations-Lexikon (MGKL). The lexeme maidan seems to have fallen out of the modern German vocabulary system, leaving just a faded trace 
in the language consciousness, though being present in the cognitive background.

The following procedure of componential analysis implies distinguishing what we call 'simple summands' or 'allonyms' of the lexeme within the body of every gloss. Such parts of the semantic structure - expressed either by a word or a word group - are regarded as elementary units of content that constitute a body of the word meaning. The procedure, once introduced by Kobyakova \& Yehorova $(2011,2012)$, rests on the following principles:

1 ) the sampling enter only those units that either fall under the law of morphological identity (e.g. table (noun) - piece [of furniture] (noun)), or reveal meaningfulness for apprehending the nature of the denotatum (e.g. units like meal, flat, legs, restaurant, writing that explicate the functionality or other important references to the headword ('table'));

2) conjugates are treated as one common summand;

3) where possible, the method of semantic clustering is applied to synonymous units with a slight or insignificant deviation of meanings (e.g. eating, food, meal); in the sampling, they are marked by '='sign;

4) dialectal, colloquial and other socially stratified units also enter the sampling on the ground that the current analysis of the notional layer of concept requires featuring the whole spectrum of associations with the denotatum.

The sets of semantic summands are distributed between the zones of convergence and divergence. Each semantic summand in the sampling acquires its index of occurrence. Its value gives ground for determining some conceptual feature pertaining to the notional layer of the MAIDAN-concept. Further reflections and interpretations engage the elements of discursive analysis of media sources.

\section{Results and discussion}

\subsection{Maidan: capturing the gist}

Etymologisches Wörterbuch der europäischen Wörter orientalischen Ursprungs by Lokotsch (1927: 88) states Arabic origin of lexeme maidan with the common meaning 'place' as it appears in Germanic, Slavic and Romance languages. The scope of the semantic content of the lexeme is exposed by Wehr (1976: 933):

ميدان maidān, mīdān pl. مَنَادِين mayādìn square, open place, open tract; field; arena; battleground, battlefield; combat area, fighting zone; race course, race track; playground (fig); field, domain, line, sphere of activity. 
However, other sources trace the Iranian origin of the nomination. Persian cognate -dan (دان) used as an affix bears the meaning of 'container' (Johnson, 1852: 553) that is cognitively associated with space organisation. F. Corriente (2008: 375) confirms the locative meaning of the Iranian suffix but finds questionable the base itself. Quoting Šir (1990: 148), who derives the base from Pahlavi may meaning 'wine' and thus refers Neo-Persian maydan to 'tavern or place where wine was consumed, and later a battlefield', Corriente finally agrees with Šìr's assumption:

... not only because drinking parties usually ended up in bitter scuffles, but also because in Arabic poetry, since pre-Islamic times, the metaphors of death in battle as the cup offered by the champions to their foes, and of the battle as the place where such deadly rounds are served had become commonplace (Corriente, 2008: 375).

Surprisingly, the $21^{\text {st }}$-century image of the Ukrainian Maidan as a place for fighting for people's rights and democratic principles calls up this image of a battlefield in the concept's long-term memory.

Finally, some sources (Wiktionary; Cătălin, 2014) narrow the origin of the name maidan down to Proto-Indo-European reconstruction *médhyos. J. Pokorny states the meaning of the root medhi-, medhio- as 'middle' echoing in other European languages: Gk. jźoos, Lat. medius; Goth. midjis, O.Bulg. mežda 'road', Rus. mežá 'limit, boundary', O. Bulg. meždu 'between'; here also probably adheres the meaning 'wood from the borderline': O.Pruss. median, Ltv. mežs 'wood, forest, spine', and Lith. mẽdžia 'tree' (Starostin G. \& A. Lubotsky, 2007). This latter semantic trace becomes obvious in the range of meanings that lexeme maidan features in modern dictionaries of Russian and Ukrainian.

Considering all these historic and language facts, it is possible to outline main conceptual features that form the informative core of MAIDAN-concept:

1) maidan is a place, i.e. it has a spatial organisation;

2) maidan is open, lying in the middle and thus clearly seen;

3) maidan serves for accumulation purposes ('container'-image);

4) maidan serves for carrying out some activities or holding events ('wine consume', 'combat', 'race').

The defined features help to figure out that the etymon of maidan was the image of an open medial area that presumably accumulated masses of people gathering for some interaction. These features are treated as prototypical for the evolvement of the notional layer of MAIDAN-concept in distant linguocultures. 


\subsection{Maidan: "What's in my name for you?"}

European cultures adopted the 'oriental' concept along with its name through historic connections between the Slavs and Turkic tribes, mostly Tatars, and Turks. Supposedly, it is after the spread of Polish-Lithuanian Commonwealth onto the Ukrainian territories that maidan spread to other European cultures and languages. With every new spiral in its history, MAIDAN got more extended with some of its parts getting more vivid or obscure, depending on the concept's importance within a particular cultural space of functioning.

Semantic decomposing of lexemes maidan in English, Maidan in German, and майдан in both Ukrainian and Russian (see Tables 1-4) exposes six dimensions of semantic correlates: English-German, German-Russian, German-Ukrainian, Ukrainian-English, Russian-Ukrainian, Russian-English (clockwise in Table 5).

Table 1. Semantic profile of MAIDAN nominations in English.

\begin{tabular}{|c|c|c|}
\hline Dictionary & Dictionary entry & Semantic summands \\
\hline OED & $\begin{array}{l}\text { (in South } \underline{\text { Asia }}^{1} \text { ) an open } \\
\text { space }^{3} \\
\underline{\text { in or near a town }}^{4} \text {, used } \\
\text { as a parade }^{5} \text { ground } \\
\text { ever for } \\
\underline{\text { events }}^{7} \text { such as public } \\
\text { ings }^{9}\end{array}$ & $\begin{array}{l}\text { Asia, open, space, town, } \\
\text { ground, event = parade, } \\
\text { public, meeting }\end{array}$ \\
\hline CIDE & $\begin{array}{l}\text { in various parts of } \underline{\text { Asia }}^{1} \text {, an } \\
\text { open }^{2} \underline{\text { space }}^{3} \text {, as for } \underline{\text { military }}^{4} \\
\text { exercises, or for a } \underline{\text { market }}^{5} \\
\text { place; an open grassy } \\
\text { an esplanade }\end{array}$ & $\begin{array}{l}\text { Asia, open, space, tract = } \\
\text { esplanade, military, mar- } \\
\text { ket, grassy }\end{array}$ \\
\hline
\end{tabular}

Table 2. Semantic profile of MAIDAN nominations in German.

\begin{tabular}{|c|c|c|}
\hline Dictionary & Dictionary entry & Semantic summands \\
\hline BKKL & großer $^{1} \underline{\text { Platz }}^{2}$, Marktplatz $^{3}$ & $\begin{array}{l}\text { groß ('big, large'), Platz } \\
\text { ('space, area'), Marktplatz } \\
\text { ('marketplace') }\end{array}$ \\
\hline MGKL & 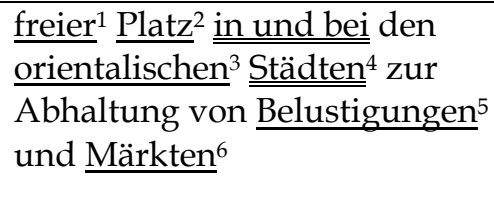 & $\begin{array}{l}\text { frei ('free, open'), Platz } \\
\text { ('space, area'), Städte } \\
\text { ('towns'), orientalisch ('ori- } \\
\text { ental'), Belustigung ('amu- } \\
\text { sement'), Markt ('market') }\end{array}$ \\
\hline
\end{tabular}


Table 3. Semantic profile of MAIDAN nominations in Russian.

\begin{tabular}{|c|c|c|}
\hline Dictionary & Dictionary entry & Semantic summands \\
\hline DTS & 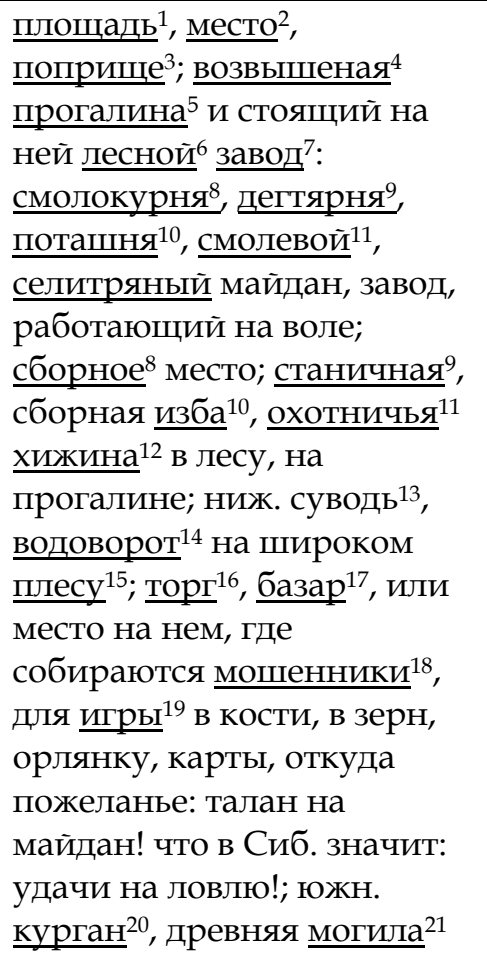 & $\begin{array}{l}\text { площадь ('area, square') = } \\
\text { место ('place'), поприще } \\
\text { ('field, sphere of activity'), } \\
\text { возвышенный ('elevated'), } \\
\text { прогалина ('glade'), лесной } \\
\text { ('forest'), завод ('plant'), } \\
\text { смолокурня = дегтярня ('tar } \\
\text { plant') = смолевой ('tar'), } \\
\text { поташня ('potash plant'), } \\
\text { селитряный ('niter'), } \\
\text { сборный ('assembly'), } \\
\text { станичный ('related to stan- } \\
\text { itsa, а Созsack village'), изба } \\
\text { ('реasant's hut') = хижина } \\
\text { ('саbin'), охотничий ('hunt- } \\
\text { ing'), суводь = водоворот } \\
\text { ('whirlpool'), плес ('reach (of } \\
\text { river)'), торг = базар ('mar- } \\
\text { ket'), мошенники ('swin- } \\
\text { dlers'), игра ('game'), } \\
\text { курган ('burial mоund') = } \\
\text { могила ('grave') }\end{array}$ \\
\hline UTS & 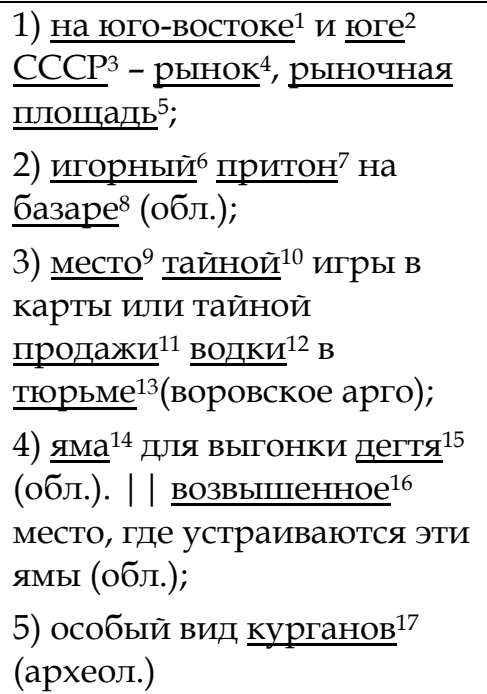 & $\begin{array}{l}\text { на юго-востоке ('in the } \\
\text { South-East') = на юге ('in the } \\
\text { South'), СССР ('USSR'), } \\
\text { рынок ('market') = } \\
\text { рыночная площадь ('mar- } \\
\text { ketplace') = базар ('market'), } \\
\text { игорный ('gaiming, gam- } \\
\text { bling'), притон ('den'), } \\
\text { место ('place'), тайный ('se- } \\
\text { cret'), продажа ('sale'), } \\
\text { водка ('vодkа'), тюрьма } \\
\text { ('prison'), яма ('pit'), деготь } \\
\text { ('tar'), возвышенный ('еle- } \\
\text { vated'), курган ('burial } \\
\text { mound') }\end{array}$ \\
\hline
\end{tabular}


Table 4. Semantic profile of MAIDAN nominations in Ukrainian.

\begin{tabular}{|c|c|c|}
\hline Dictionary & Dictionary entry & Semantic summands \\
\hline SUM & 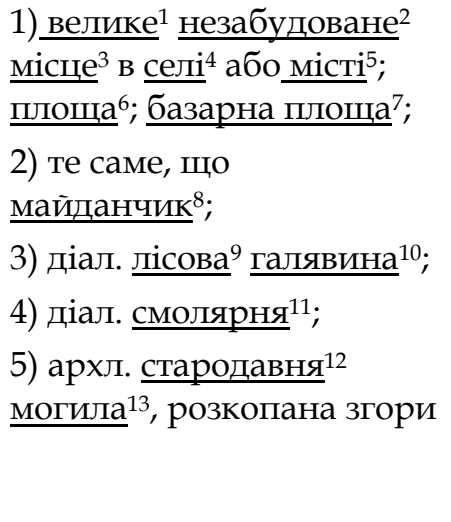 & $\begin{array}{l}\text { великий ('large'), } \\
\text { незабудований ('undevel- } \\
\text { ореd'), місце ('place, site') = } \\
\text { площа ('area, square'), село } \\
\text { ('village'), місто ('town, ur- } \\
\text { ban'), базарна площа ('mar- } \\
\text { ketplace'), майданчик } \\
\text { ('ground, area'), лісовий } \\
\text { ('forest'), галявина ('glade'), } \\
\text { смолярня ('tar plant'), } \\
\text { стародавній ('ancient'), } \\
\text { могила ('grave') }\end{array}$ \\
\hline ZUEK & 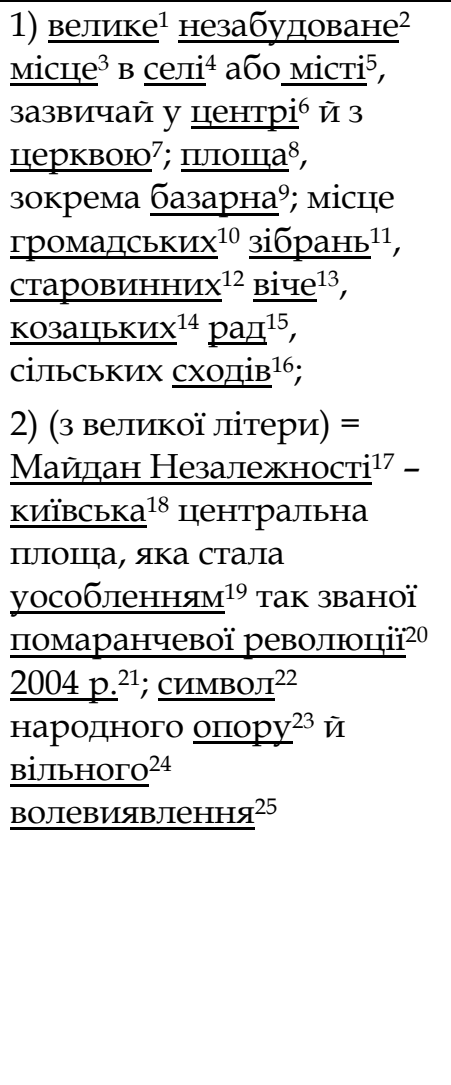 & 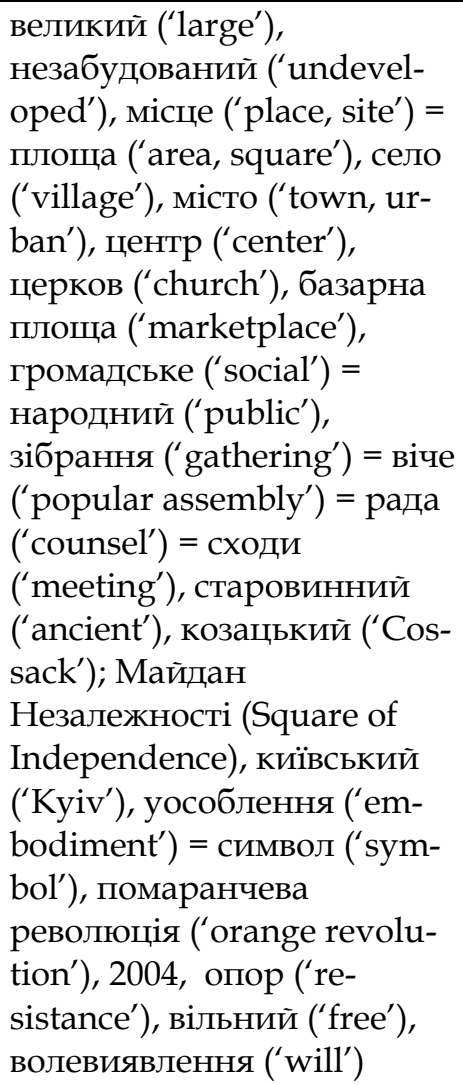 \\
\hline
\end{tabular}


Table 5. Semantic convergences and divergences of MAIDAN nominations in distant languages.

\begin{tabular}{|c|c|c|c|}
\hline $\begin{array}{r}\text { Germanic } \\
\text { languages }\end{array}$ & English & $\begin{array}{l}\text { (4) space, area } \\
\text { (3) Asia; oriental } \\
\text { (3) open, free } \\
\text { (3) market(-place) } \\
\text { (2) town } \\
\text { (2) event (parade, } \\
\text { amusement) }\end{array}$ & German \\
\hline Russian & $\begin{array}{l}\text { (4) area, space, } \\
\text { place } \\
\text { (3) open, glade (= } \\
\text { open space in the } \\
\text { forest) } \\
\text { (3) market(-place) } \\
\text { (2) meeting, as- } \\
\text { sembly } \\
\text { (2) town, stanitsa }\end{array}$ & & $\begin{array}{l}\text { (4) area, space, } \\
\text { place } \\
\text { (3) market(- } \\
\text { place) } \\
\text { (2) free, open, } \\
\text { glade } \\
\text { (2) towns, } \\
\text { stanitsa }\end{array}$ \\
\hline $\begin{array}{l}\text { (4) area, } \\
\text { square, place } \\
\text { (4) market(- } \\
\text { place) } \\
\text { (3) glade (= } \\
\text { open space), } \\
\text { free unde- } \\
\text { veloped } \\
\text { (3) tar (plant) } \\
\text { (3) burial } \\
\text { mound, } \\
\text { grave } \\
\text { (3) stanitsa, } \\
\text { village } \\
\text { (2) forest } \\
\text { (2) plant } \\
\text { (2) Cossack } \\
\text { (2) meeting, } \\
\text { assembly }\end{array}$ & 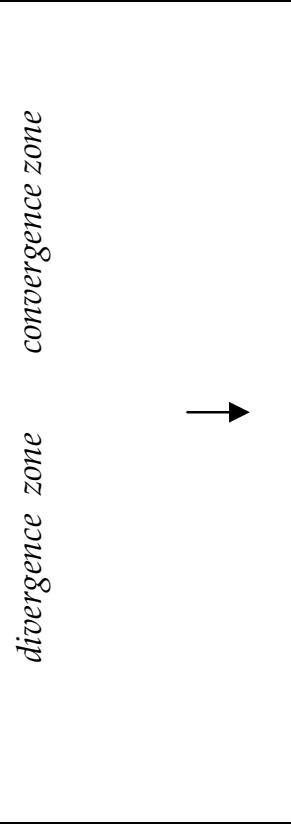 & $\begin{array}{l}\text { (8) area, space, } \\
\text { place } \\
\text { (7) market(-place) } \\
\text { (6) open, free, un- } \\
\text { developed, glade } \\
\text { (5) stanitsa, village } \\
\text { / town } \\
\text { (4) meeting, assem- } \\
\text { bly / event } \\
\text {-------------- } \\
\text { (3) Asia; oriental } \\
\text { (3) burial mound, } \\
\text { grave } \\
\text { (2) forest } \\
\text { (2) plant } \\
\text { (2) Cossack }\end{array}$ & 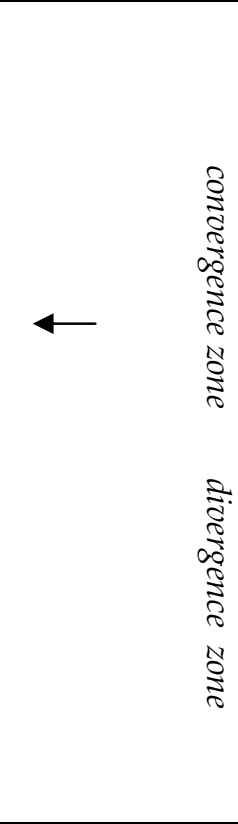 \\
\hline Ukrainian & $\begin{array}{l}\text { (4) undeveloped, } \\
\text { open } \\
\text { (4) space, place, } \\
\text { area, square } \\
\text { (3) town, village }\end{array}$ & & $\begin{array}{l}\text { (4) space, area, } \\
\text { place, site } \\
\text { (4) market(- } \\
\text { place) } \\
\text { (3) large, big }\end{array}$ \\
\hline
\end{tabular}




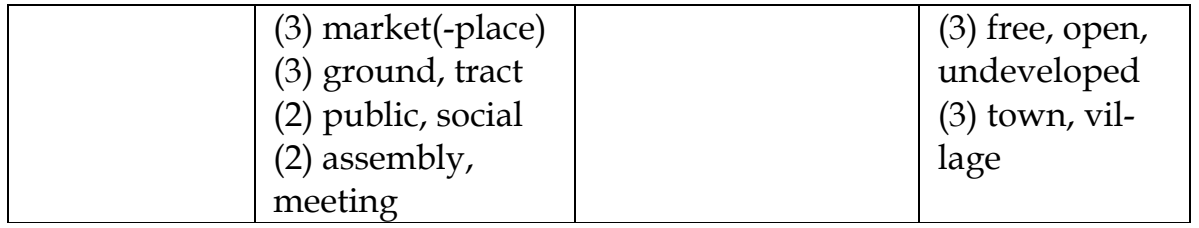

The degree of convergence within the set of semantic summands is determined by the index of occurrence. This index stands for the frequency with which each semantic summand (along with its immediate semantic relatives) appears in the definitional texts of the analysed lexicographic sources. Semantic distribution of the semes and their juxtaposition shape the zones of convergence and divergence.

Convergence zone features a set of components of notional meaning shared by all four languages compared. These facts we regard as conceptual features of the notional layer of MAIDAN-concept. Thus, in all four language systems:

1) maidan is primarily associated with a kind of spatial organisation which as a fact of the tangible world can be sensually perceived;

2) maidan is intended for specific purposes; namely, it serves as an arena for commercial dealings between people;

3) maidan is designed as an open undeveloped area with a free access and a broad activity on it;

4) maidan is typically located within a kind of settlement (mostly rural);

5) maidan is associated with people's gathering for different purposes and events.

Hence, the universal elements in the semantic content of the name maidan as featured in both groups of languages are location, openness, affiliation with settlement, assembly, whereas the shared denotata are 'area (square)', 'place', 'market(-place)', and 'glade'. In terms of Trier's (1931) linguistic field theory, we regard the defined semes with frequency index from 8 to 4 as the conceptual features constituting the nuclear and perinuclear zones of the notional layer of MAIDAN-concept; the rest semantic summands spread about the near and remote periphery of the field.

All semantic summands found in the glosses without cross-reference (i.e. only in Germanic or only in Slavic languages) constitute the slots of ethnospecific features of the concept that get revealed only on a particular linguocultural ground. It is noteworthy that Germanic languages bare a fixed original association of maidan with oriental (predominantly Asian) realities, whereas Slavic languages demonstrate a full adaptation of the concept in both Russian and Ukrainian cultures with its subsequent internal develop- 
ment (cf. toponymic indices 'South, South-East, USSR, Siberia, southern; Kyiv, Square of Independence'). Within the Slavic cultures, maidan has developed the meaning of 'burial mound or grave' which not only recalls the core conceptual features of 'container' and 'place for specific activities (inclusive of combat)' but also takes on special symbolism in the context of tragic (Euro)Maidan events in February 2014.

Lexicographic data show that in Slavic cultures maidan may also refer to an open place in the forest (or glade). Moreover, the core conceptual feature 'field of activity' is broadened by association with a plant or simply a pit for producing tar located in the forest area. On the contrary, Germanic languages show a weak association of maidan with an object of a natural landscape (the only semantic summand traced is 'grassy') and rather feature maidan as a fact of urbanisation. Alongside, in Ukrainian maidan may refer to realities of both towns and villages, whereas Russian does not go beyond the historic reference to stanitsa - primarily a Cossack village, now a type of rural localities predominantly in the South-West of Russia. This fact proves an inner differentiation of the concept content within the Russian and Ukrainian linguocultures.

Another culture-bound feature of MAIDAN is its historic association with Cossacks - the members of democratic, self-governing, and semi-military communities in Russia and Ukraine. Two of four glosses in Slavic group of dictionaries refer to this historic reality via units 'станичная изба' (staničnaja $i z b a)$ - an administrative, executive, and judicial office in a Cossack village, and 'козацька рада' (kozacka rada) - a Cossack assembly or council often military in nature. Though some Cossack communities have been formally preserved till nowadays, they are no longer treated as separate military or self-governing units; however, the MAIDAN-concept stores these ethnic cultural vestiges of the past in the corresponding slots of its notional layer.

Of note is that the Russian language dictionaries only fix negative connotations of the maidan nomination. Historically, maidan could refer to a part of a marketplace where people met for gambling. Maidan could be associated with a den or a place where swindlers met. According to Dal (DTS, 2014: 2761-2762), in thieves' argot, it also meant a place for secret gambling or secret selling of vodka in a prison (we assume that such reference may have metaphorically developed from the original seme 'battlefield, combat area' where the winner gets all the trophies). Such connotations have not developed in the notional layer of the MAIDAN-concept in the Ukrainian language. However, they managed to shape the evaluative layer of the concept, especially in the context of 2013-2014 when Maidan was heavily criticised by the then Ukrainian government and its other opponents:

(2) "Terrorists from the "Maidan" (Independence Square) seized dozens of people and beat them. I am officially stating that these are criminals who 
must answer for their action,' Azarov told a cabinet meeting yesterday. Azarov accused opposition leaders of inciting 'criminal action' by calling for anti-government protests, which he said destabilised the situation in Ukraine, a large former Soviet republic of 46 million people. (The Herald, 23 January 2014)

(3) 'The government would like the world to believe that those on Maidan are just terrorists and extremists to justify the bloodshed, ... that those on Maidan are armed with firearms and rioting,' Kiev protester MaiaKiev told CNN iReport. 'But it's not a riot ... It's a revolution of dignity.' (CNN International Edition, 19 February 2014)

The utmost periphery of the notional layer belongs to the semantic summands that have recently entered occasional lexicographic sources and represent a neologism (semantic derivative) from the perspective of academic lexicography. The entry is found in Signs of the Ukrainian Ethnic Culture, where the second part of the gloss states:

(capitalised) $=$ Square of Independence - Kyiv central square which became an embodiment of the so-called orange revolution of 2004; symbol of public resistance and free will (ZUEK, 2006: 349).

\subsection{Maidan: systemic vs. non-systemic meanings or context as a way to systematisation}

Academic language dictionaries shed no significant light on what Euromaidan is. Even the newest one - Signs of the Ukrainian Ethnic Culture - merely connects maidan to a specific location in Kyiv and its symbolism in association with Orange Revolution of 2004 (name strangely not capitalised in the glossed text). The first part of the compound Euro-, which is frequently omitted in discourse, bears a distinctive feature of Maidan of 2013-2014 in its reference to European integration and to the 'European choice' of Ukrainians, as opposed to the decision of the government to stop the preparations for signing the agreement with the EU and strengthen the ties with Russia. However, literal decomposing of the lexeme Euromaidan into 'Euro(pean) + Square of Independence' may lead to disambiguation as the toponymy of Kiev features two different locations: Maidan (Square) of Independence and European Square (not Maidan!).

We hold the opinion that Maidan/maidan is a complex denomination that resulted in symbolisation of the fact of reality, a composition of notions, modification, and rethinking of the already existing word in the language system due to attributing this fact of reality to a certain category. Thus, we believe that revealing the actual meaning of Maida/maidan lexemes is possible only through contextual and discourse analysis. 
On the one hand, Maidan/maidan is a typical toponym, frequently an urbanonym (from Lat. urbanus 'of or belonging to a city; urban' + Gr. övopa 'name') present in a range of kin and distant cultures. Cf.:

(3) Maidan - a village in Lukivtsi, Vyzhnytsia Raion, Ukraine;

Maidan - a street in Vladimir, Russia;

Maidan - a settlement in Akbulak Region, Orenburg Oblast, Russia;

Maidan - a village development committee in Arghakhanchi District, Lumbini Zone of southern Nepal;

Maidan (Tirah Maidan) - a remote valley located in the Tirah region in Khyber Agency, Pakistan;

Maidan - a village in Talachyn Raion, Vitebsk Region of Belarus;

Majdanpek (Maidan) - a town and municipality in Bor District of Serbia;

Maidan Konstytutsii (Constitution Square) - a metro station in Kharkiv, Ukraine;

Maidan Shar - the capital of Wardak province of Afghanistan;

The Maidan - the largest urban park in Kolkata in the Indian state of West Bengal;

Majdan - a village in the administrative district of Gmina Wojstawice, Lublin Voivodeship, Poland;

Majdan - a settlement in Dvor municipality of Croatia;

Maydan - a town in Batken Region of Kyrgyzstan;

Maydan al Shajara (The Tree Square) - a major town square in Benghazi, Libya;

Medan - the capital of North Sumatra province in Indonesia;

Meydan - a village in Mahur Berenji Rural District, Khuzestan Province in Iran;

Dubai Meydan city - a new development under construction in Ras Al Khor area of Dubai, UAE;

Taksim Meydanı (Taksim Square) - a square situated in the European part of Istanbul, Turkey;

Midan Tahrir (Liberation Square) - a major public town square in Downtown Cairo, Egypt;

Al-Midan - neighbourhood and municipality in Damascus, Syria;

Tavisuplebis moedani (Freedom Square) - the central square of Tbilisi, capital of Georgia. (Wikipedia)

On the other hand, proper noun Maidan appears in foreign (English and German) media with reference to Euromaidan events of 2013-2014. These media contexts cover five major conceptual areas where Maidan may denote: 
1. Maidan Nezalezhnosti (Independence Square) - the central square of modern Kiev, the capital of Ukraine:

(4) A number of protesters and police have lost their lives in violent clashes in central Kiev, Ukraine, in demonstrations against the government of President Viktor Yanukovych. Protests have centred on the capital's Independence Square, also known as the Maidan, where protesters had set up camp over a number of months. (BBC.COM, 20 February 2014)

(5) Bei dem von ukrainischen Demonstranten besetzten Unabhängigkeitsplatz (Maidan) in Kiew fließt nach der Beseitigung von Barrikaden erstmals seit Monaten wieder weitgehend der Verkehr. (HANDELSBLATT.COM, 10. August 2014)

2. Maidan movement - a specific kind of national mass protests in Ukraine, a tool for gaining public control over the government in the range of specific forms:

(6) Indeed, a journalist from Donetsk, the ruling party's power base, noted that the Maidan is just as important for those who are against it as those who support it; as the institutions of the past crumble, the Maidan's aims of freedom, self-reliance, self-governance, respect, dignity, and justice are a compelling counter-narrative to the sterile myths of the Soviet pastfew people anywhere in the country see a future tied to Russia. (The Globe and Mail, 21 February 2014)

(7) In 2010, the Tax Maidan protests - protests by entrepreneurs against the bureaucratisation of relationships with business and the state - was broken up. (New Eastern Europe, 22 August 2013)

(8) Es handelt sich nicht um Einzelfälle. Seit dem 22. Januar wird in Kiew Dmytro Bulatow vermisst. Der 35-Jährige ist einer der Anführer beim sogenannten "Automaidan". So nennt sich eine Gruppe meist junger Leute mit eigenen Autos, die sich zu einer treibenden Kraft hinter den Protesten entwickelt hatte. (DW.COM, 27. Januar 2014)

3. Maidan event - one of several historically recorded realisations of national protests in Ukraine, an act of exercising public politics itself:

(9) This is "revolution" in the sense not of "forcible overthrow of government" but of the "revolution of planets around stars". And it makes the Maidan feel more significant rather than smaller - an event with its own astronomy, an epic of outer space. (London Review of Books, 19 February 2015)

(10) Wir möchten heute nur über die letzten drei Tage des Maidans sprechen, sie in Erinnerung rufen, den Menschen gedenken, die dort gestorben sind, für die Freiheit ihres Landes, für das Recht auf eigene Unabhängigkeit, für die Zukunft ihrer Kinder. Für Europa. Wir möchten über den 18. bis 20. Februar 2014 sprechen. (InformNapalm, 22. Februar 2016) 
(11) In ukrainischen Medien und sozialen Netzwerken wird inzwischen über einen möglichen "dritten Maidan" diskutiert. Gemeint ist ein Volksaufstand mit großen Kundgebungen auf dem Kiewer Maidan Nesaleschnosti (Unabhängigkeitsplatz), der 2004 und zuletzt im Winter 2013/14 zu einem Machtwechsel geführt hatte. (DW.COM, 02. May 2014)

4. Maidan protesters - people who gathered due to sharing the common idea of standing against the existing socio-political mode of life in the country and organised a fortified camp:

(14) The protesters represent every group of Ukrainian citizens: Russian speakers and Ukrainian speakers (although most Ukrainians are bilingual), people from the cities and the countryside, people from all regions of the country, members of all political parties, the young and the old, Christians, Muslims, and Jews. Every major Christian denomination is represented by believers and most of them by clergy. The Crimean Tatars' march and Jewish leaders have made a point of supporting the movement. The diversity of the Maidan is impressive: the group that monitors hospitals so that the regime cannot kidnap the wounded is run by young feminists. An important hotline that protesters call when they need help is staffed by LGBT activists. (Snyder, 2014)

(15) Gleichzeitig entreißt der Maidan, der auf der Prachtstraße Chreschtschatyk - der Kiewer Champs-Élysées - seine Zelte aufgeschlagen hat, der Klasse der Reichen "ihre symbolische Dominanz". Zu "Prada" gehen die Maidaner auf die Toilette. (Die Welt, 21. Juni 2014)

5. Maidan symbolism - any of symbolic meanings of Maidan events as perceived by its participants, supporters or witnesses:

(16) The future of this protest movement will be decided by Ukrainians. And yet it began with the hope that Ukraine could one day join the European Union, an aspiration that for many Ukrainians means something like the rule of law, the absence of fear, the end of corruption, the social welfare state, and free markets without intimidation from syndicates controlled by the president. (Snyder, 2014)

(17) What was once a square of mixed meaning, which seemed to reflect Ukraine's incomplete independence, has instead become a spiritual lodestar for the entire nation and a powerful symbol of the new Ukraine. (Business Ukraine, 18 June 2015)

(18) Die Botschaft der westlichen Medien ist eine andere. Dort wird der Maidan als Erwachen der Zivilgesellschaft gedeutet, als Aufbruch in die Zukunft. (Berliner Zeitung, 13. Dezember 2013).

(19) Doch die Proteste durchliefen den komplizierten und tragischen Prozess, wie er mit der Entstehung einer neuen Zivilgesellschaft einhergeht. Ja, einer Zivilgesellschaft, denn der Maidan ist nicht nur ein Platz im Zentrum der ukrainischen Hauptstadt mit einigen hunderttausend unzufrie- 
denen Bürgern darauf. "Maidan" ist der Schlüssel zum Verständnis der grundlegenden Veränderungen in der ukrainischen Gesellschaft. (Ostpol: Das Osteuropamagazin, 30. Januar 2014).

In one of the articles on Ukraine, Housum Professor of History at Yale Timothy Snyder (2014) summarises the development of MAIDAN-concept in the case of Ukraine:

... a maidan now means in Ukrainian what the Greek word agora means in English: not just a marketplace where people happen to meet, but a place where they deliberately meet, precisely in order to deliberate, to speak, and to create a political society. During the protests, the word maidan has come to mean the act of public politics itself, so that for example people who use their cars to organise public actions and protect other protestors are called the automaidan.

This publication is one of many that trace inconsistency in using either maidan or Maidan when referring to different denotata. Supposedly, this inconsistency originates, on the one hand, from the lack of conventions as to the use of these lexemes in local Ukrainian media, and, on the other hand, from the role and influence of social networking that takes advantage of using simplified language and spelling for information spread. We regard these facts as those preventing the newly developed conceptual features of MAIDAN from acquiring systemic status within language systems.

\section{Concluding remarks}

From the above discussions, it turns out that revealing the nature of ethnocentric concepts through language manifestations is a complex process that requires applying both lexicographic and discourse analysis. This paper mainly focuses on the first stage of the conceptual analysis and outlines the vectors of subsequent fields of investigation. We see a thorough lexicographic analysis of the concept's key nomination as an indispensable part of revealing the notional content and informative core of the analysed concept, as well as understanding the prime motivation for designating the fact of reality.

While studying ethnocentric concepts in cross-language and crosscultural dimension, methods of comparative analysis prove their validity in revealing both common and authentic conceptual features. The sets of conceptual features give reasons to assess the levels of conceptual development in time and space. Thus, current analysis has shown that the set of meanings inherent in the concept's key nomination maidan in the group of Germanic languages remained stock-still from the time of entrance of this word into the language systems of English and German. Alongside, the range of different meanings the nomination maidan bears in Slavic languages is significant- 
ly wider that speaks for further development of the MAIDAN-concept on these linguocultural grounds.

The lexeme maidan entered the strata of both Slavic and Germanic language groups long ago but the systemic sets of meanings in all the compared languages do not reflect the spectrum of the actuals labelled by the lexeme. However, most of the notional conceptual features defined in the process of componential analysis may be balanced against the present-day constituents of the conceptual field of the MAIDAN-concept: Maidan is strongly associated with an open free area in the form of the central square in a city; Maidan is a place for people to assemble and openly express their thoughts, feelings, and discontent; Maidan of 2013-2014 has truly become a burial mound for more than a hundred of protesters who like historic Cossacks were fighting for their beliefs and governmental injustice.

On the one hand, linguoconceptology cannot merely rely on dictionary data in conceptual describing, as they fail to render the imagery-evaluative components allotted to the concept by the language users in present-day discourse. On the other hand, we believe that MAIDAN nominations are ready for a thorough lexicographic revision in all languages analysed due to a number of reasons; their long-term usage on the global scale (2004-2018), a substantial number of citations from a vast range of sources, and the significance of the concept for the language users and its obvious likelihood to stand the test of time.

\section{References}

Boldyrev, Nikolay (2000). Cognitive Semantics: Lectures in English Philology. Tambov: Tambov University Publishing.

Cătălin, Constantin (2014, December 12). Maidan. Cultura and Societate, 497. Retrieved from http:/ / revistacultura.ro/nou/2014/12/maidan.

Evans, Vyvyan (2009). How Words Mean: Lexical Concepts, Cognitive Models and Meaning Construction. Oxford, UK: Oxford University Press.

Freidin, Gregory (1987). A Coat of Many Colors: Osip Mandelstam and His Mythologies of Self-presentation. Berkeley, Los Angeles and London: University of California Press.

Karasik, Vladimir (2005). Этноспецифические концепты. Введение в когнитивную цингвистику [Ethnospecific concepts. Introduction to Cognitive Linguistics]: 61-105.

Karaulov, Yuriy (1981). Лингвистическое конструирование и тезаурус литературного языка. [Linguistic Construal and Thesaurus of Literary Language]. Moscow: Nauka.

Kobyakova, Iryna, Olesia Yehorova (2011). Semantic identification and quantitative parameters of the concept QUANTITY in the English language. Kharkiv V.N. Karazin National University Journal 954: 94-101. 
Langacker, Ronald W. (1987). Foundations of Cognitive Grammar. (Vol. 1). Stanford: Stanford University Press.

Nikitin, Mihail (2007). A Course in Linguistic Semantics (2nd edn.). St. Petersburg: A.I. Gertsen RGPU Publishing.

Oriikiriza, Celestino (2014). Elicitation and arrangement of conceptual meanings. Lexikos 24: 225-250.

Popova, Zinaida, Iosif Sternin (2007). Cognitive Linguistics. Moscow: AST.

Prykhodko, Anatoliy (2013). Концепты и концептосистемы.[Concepts and Conceptual Systems]. Dnepropetrovsk: Belaya Ye.A.

Schwarz, Monika (1996). Einführung in die Kognitive Linguistik. Tübingen/Basel: Francke.

Talmy, Leonard (2000). Toward a Cognitive Semantics. (Vol. 1). Cambridge, MA: MIT Press.

Trier, Jost (1931). Der Deutsche Wortschatz im Sinnbezirk des Verstandes. Heidelberg: Carl Winter.

Tyshchenko, Kostiantyn (2010). Всеслов'янські складники української мови. Мандрівець 3 [All-Slavic Constituents of the Ukrainian language. Mandrivets 3]: 65-75.

Vorkachev, Sergey (2005). Вариативные и ассоциативные свойства телеономных мингвоконцептов [Variation and Associative Features of Teleonomic Concepts]. Volgograd: Paradigma.

Yehorova, Olesia (2012). Linguistic and Cognitive Aspects of the Indefinite Quantity Actualization in the English-Language Discourse (Unpublished doctoral dissertation). Kherson State University, Kherson.

\section{Dictionaries}

BKKL = Brockhaus' Kleines Konversations-Lexikon (1911). Fünfte, vollständig neubearbeitete Auflage. In zwei Bänden. Zweiter Band. Leipzig: F.A. Brockhaus.

CIDE $=$ Collaborative International Dictionary of English (2012). Version 0.51. Retrieved from http:/ / gcide.gnu.org.ua.

Corriente, Federico (2008). Dictionary of Arabic and Allied Loanwords: Spanish, Portuguese, Catalan, Galician and Kindred Dialects. Leiden - Boston: Brill.

DTS = Dal, Vladimir Ivanovich (2014). Explanatory Dictionary of the Live Great Russian Language. Moscow: Directmedia.

Johnson, Francis (1852). Dictionary, Persian, Arabic and English. London: W.H. Allen \& Co. under the patronage of the Honourable East-India Company.

LSJ = Liddell, Henry George, Robert Scott (eds.) (1940). A Greek-English Lexicon. Revised and augmented throughout by Sir Henry Stuart Jones with the assistance of. Roderick McKenzie. Oxford: Clarendon Press.

Lokotsch, Karl (1927). Etymologisches Wörterbuch der europäischen Wörter orientalischen Ursprungs. Heidelberg: Carl Winter's Universitätsbuchhandlung.

Maidan (2017). In: Wiktionary, the free dictionary. Retrieved from. https://en.wiktionary.org/wiki/maidan. 
MGKL = Meyers Großes Konversations-Lexikon. Ein Nachschlagewerk des allgemeinen Wissens (1908). Sechste, gänzlich neubearbeitete und vermehrte Auflage. Dreizehnter Band: Lyrik bis Mitterwurzer. Neuer Abdruck. Leipzig und Wien: Bibliographisches Institut.

OED = Stevenson, Angus (ed.) (2010). Oxford English Dictionary. Third edition. Oxford: Oxford University Press.

SUM = Buriachok, Andrii, Ivan Bilodid (Eds.) (1973). Slovnyk Ukraynskoyi Movy. (Vol 4). Kyiv: Naukova Dumka.

Starostin, George, Alexander Lubotsky (eds.) (1959). Proto-Indo-European Etymological Dictionary: A Revised Edition of Julius Pokorny's Indogermanisches Etymologisches Wörterbuch. Retrieved from http://indo-european.info/pokorny-etymological-dictionary/index.htm.

Šīr, Al-Sayyid Addi (1990). Mu'jam al-alfaz al-farisiyah al-mu'arrabah [A Dictionary of Persian Loanwords in the Arabic Language]. Bayrut: Maktabat Lubnan.

UTS = Ushakov, Dmitriy (2014). Explanatory Dictionary of the Russian Language. Moscow: Adelant.

Wehr, Hans (1976). A Dictionary of Modern Written Arabic (Arabic-English). Ed. by J. Milton Cowan, 3rd . ed., New York: Spoken Language Services, Inc.

ZUEK = Zhaivoronok, Vitaliy (2006). Signs of the Ukrainian Ethnic Culture: dictionaryreference. Kyiv: Dovira.

\section{Corpus}

Big picture: Close-up of Kiev's Independence Square (2014, February 20). BBC. Retrieved from http://www.bbc.com/news/world-europe-26257542.

Bilak, Daniel (2014, February 21). On the Maidan, the birth of a real Ukrainian civil society. The Globe and Mail. Retrieved from http://www.theglobeandmail. com/opinion/on-the-maidan-the-birth-of-a-real-ukrainian-civil-society/ article17025424.

Dickinson, Peter (2015, June 18). Maidan metamorphosis reflects Ukraine's coming of age. Business Ukraine. Retrieved from http://bunews.com.ua/society/item/ maidan-metamorphosis-reflects-ukraines-coming-of-age.

Esch, Christian (2013, Dezember 13). Auf dem Maidan in Kiew: Stammesgesellschaft definiert ihre Grenzen. Berliner Zeitung. Retrieved from http:/ /www.berlinerzeitung.de/kultur/auf-dem-maidan-in-kiew-stammesgesellschaft-definiertihre-grenzen-1157746.

Euromaidan. Wikipedia, the free encyclopaedia. Retrieved from. https://en.wikipedia.org/wiki/Euromaidan.

Goncharenko, Roman (2014a, Januar 27). Gekidnappt, geschlagen, getötet. DW. Retrieved from http://dw.com/p/1AxUk.

Goncharenko, Roman (2014b, Mai 02). Ukraine - Droht der dritte Maidan? DW. Retrieved from http://dw.com/p/1Bsua.

Kabachiy, Roman (2013, August 22). Ukraine vs. Yuri Barabash. New Eastern Europe. Retrieved from http://neweasterneurope.eu/old_site/articles-and-commentary/838-ukraine-vs-yuri-barabash. 
Margolina, Sonja (2014, Juni 26). Wie die Maidan-Bewegung mit Europa hadert. WELT. Retrieved from http://www.welt.de/kultur/literarischewelt/article 129464605/Wie-die-Maidan-Bewegung-mit-Europa-hadert.html.

Pomerantsev, Peter (2015, February 19). Diary: Iammmmyookkraaanian. London Review of Books. Retrieved from http://www.lrb.co.uk/v37/n04/peterpomerantsev/diary.

Schlegel, Irina (2016, Februar 22). In Erinnerung an die Revolution der Würde: 18.20. Februar 2014 in Kiew. Inform Napalm. Retrieved from https://informnapalm. org/de/15215-2.

Snyder, Timothy (2014, March 20). Fascism, Russia, and Ukraine. The New York Review of Books. Retrieved from http://www.nybooks.com/articles/2014/03/20 / fascism-russia-and-ukraine.

Walsh, Nick Paton, Greg Botelho, \& Victoria Butenko (2014, February 19). Truce declared in bloodied Ukraine, but will it last through talks? CNN International Edition. Retrieved from http://edition.cnn.com/2014/02/19/world/europe /ukraine-protests.

Unabhängigkeitsplatz in Kiew: Maidan ist wieder frei von Barrikaden (2014, August 10). HANDELSBLATT.COM. Retrieved from http://www.handelsblatt.com/ politik/international/unabhaengigkeitsplatz-in-kiew-maidan-ist-wieder-freivon-barrikaden/10314402.html.

Violence erupts in Ukraine (2014, January, 23). The Herald. Retrieved from http:/ / www.herald.co.zw/violence-erupts-in-ukraine.

Zhadan, Serhij (2014, Januar 30). System der Selbstzerstörung. Ostpol: Das Osteuropamagazin. Retrieved from http://www.ostpol.de/beitrag/3858-system_der_ selbstzerstoerung.

\section{Authors' addresses:}

Olesia Yehorova

Sumy State University,

2, Rymskogo-Korsakova str.

40007, Sumy

Ukraine

e-mail: o.egorova@gf.sumdu.edu.ua

Antonina Prokopenko

Sumy State University,

2, Rymskogo-Korsakova str.

40007, Sumy

Ukraine

e-mail: a.prokopenko@gf.sumdu.edu.ua 
Received: June 3, 2018

Accepted for publication: October 17, 2018 